\title{
Pair-matched study of cryopreserved versus native graft in adult and pediat- ric recipients of allogeneic hematopoietic stem cell transplantation
}

Elena V. Babenko, Ivan S. Moiseev, Mikhail M. Kanunnikov, Alexandr L. Alyanskiy, Dmitrii E. Pevcov, Anastasia V. Frolova, Anna A. Osipova, Tatyana A. Bykova, Olesya V. Paina, Elena I. Darskaya, Ludmila S. Zubarovskaya, Sergey N. Bondarenko, Inna V. Markova, Boris V. Afanasyev

R. Gorbacheva Memorial Research Institute of Children Oncology, Hematology and Transplantation, The First St. Petersburg State I. Pavlov Medical University, St. Petersburg, Russia

Dr. Ivan S. Moiseev, R. M. Gorbacheva Memorial Institute of Children Oncology, Hematology and Transplantation, I. P. Pavlov First St. Petersburg State Medical University,

L. Tolstoy St 6-8, 197022, St. Petersburg, Russia
Phone: +7 (921) 7961951

E-mail: moisiv@mail.ru

\section{Summary}

Cryopreservation (Cryo) of a graft is a standard procedure in autologous hematopoietic stem cell transplantation (HSCT), however there is a lack of studies on the safety and efficacy of allogeneic HSCT with cryopreserved graft. We have conducted a pair-matched study in 81 patients transplanted with frozen graft and compared them to 81 control patients with fresh cell graft. The groups were matched by age, disease type and stage, conditioning, donor type, graft-versus-host disease (GVHD) prophylaxis and number of CD34-postive cells in the graft. The study group comprised $83 \%$ unrelated HSCTs, $72 \%$ of peripheral blood stem cell recipients and $40 \%$ of salvage patients. No differences were observed between the Cryo and control group in the incidence of grade II-IV acute GVHD (39\% vs 37\%, p=0.89), moderate and severe chronic GVHD (29\% vs $30 \%$, p=0.39), overall survival ( $37 \%$ vs $44 \%$, $\mathrm{p}=0.24$ ), event-free survival (35\% vs $40 \%, \mathrm{p}=0.38$ ) and GVHD-relapse-free survival ( $19 \%$ vs $25 \%, p=0.20$ ), respectively. However, non-relapse mortality (NRM) was significantly higher in the Cryo group ( $45 \%$ vs $28 \%, \mathrm{p}=0.015$ ), which was compensated by reduced relapse incidence $(21 \%$ vs $34 \%, \mathrm{p}=0.048)$.
The leading factor for NRM were trends to higher incidence of primary graft failure $(15,7 \%$ vs $6.3 \%, p=0.059)$ and sepsis during aplasia ( $24 \%$ vs $13 \%, \mathrm{p}=0.068)$. No differences were observed in the time to neutrophil and platelet engraftment. Complications of HSCT were comparable between groups except higher incidence of grade II-IV nephrotoxicity in the Cryo group ( $30 \%$ vs $10 \%$, $\mathrm{p}=0.0046$ ). In conclusion, the study demonstrated that the results of allogeneic HSCT with cryopreserved graft are comparable to native graft ones. Trends to higher primary graft failure, infectious complications and NRM should be confirmed in the multicenter studies.

\section{Keywords}

Hematopoietic stem cell transplantation, allogeneic, cryopreservation, freezing, primary graft failure. 


\section{Introduction}

Hematopoietic stem cell transplantation (HSCT) is a rapidly developing method for the treatment of various malignant and non-malignant diseases [1]. However, it requires synchronization between donor preparation to donation, conditioning regimen, donation and graft-versus-host disease (GVHD) prophylaxis. Thus situations occur, like unexpected infection in a recipient or fulminate relapse of the underling disease, when there is a dilemma whether to transplant a patient with these unexpected conditions or postpone the transplant and administer appropriate treatment. It is well known that grafting in relapse is the worst predictive factor for long-term survival [2]. On the other hand, active infections at the start of the conditioning also impact the outcome adversely $[3,4]$. Thus in the majority of cases like these the decision is made to postpone the HSCT, however this is not possible in certain situations with unrelated donors, and also when a related donor has started the stimulation with granulocyte-colony stimulating factor. In these case the graft is usually cryopreserved before infusion.

The other situation leading to cryopreservation is the poor graft cellularity collected from a donor. It is well known that low number of CD3 and CD34-positive cells in the graft significantly affect the incidence of primary graft failure and poor graft function after HSCT, which are associated with significant non-relapse mortality $[5,6]$. Unlike the related setting when CD34-selected boost could be collected after unrelated transplantation this might be difficult due to donor decision or logistics. Thus several centers prefer to receive and access the graft quality before the start of the conditioning, and then transfuse the cryopreserved graft.

Despite the safe use of freezing stage during autologous HSCT procedure, there is a lack of large comparative studies evaluating the effects of graft cryopreservation on the outcome of allogeneic HSCT. Despite the evidence that engraftment of the cryopreserved bone marrow is comparable [7, $8]$, there are reports that the risk of graft failure is increased with frozen peripheral blood stem cell (PBSC) graft [9], or the risk of the GVHD might be altered after thawing [10,11]. We conducted a single-institution pair-matched retrospective study to evaluate the impact of graft cryopreservation on the outcomes and toxicity of allogeneic stem cell transplantation.

\section{Patients and Methods}

\section{Patients and transplantation procedures}

162 patients transplanted in 2006-2017 at the I. Pavlov First St. Petersburg State Medical University were included into the study. All patients signed informed consent for the use of their medical data for research purposes, according to the Helsinki Declaration. 81 patients received the cryopreserved graft. The graft was stored with $10 \% \mathrm{DMSO}$ at $-180^{\circ} \mathrm{C}$ until the day of the transplant. The reasons for freezing were: infection before the start of the conditioning (38.3\%), relapse of the underlying disease (32.2\%), unavailability of a related donor at the time of HSCT (17.2\%), availability of the cryopreserved graft after the first donation due to restriction of
CD34 cell count (11.1\%), pregnancy before the conditioning (1.2\%). The study group (Cryo group) comprised predominantly adult patients with unrelated donors, leukemia as an underlying disease and reduced intensity conditioning. The study group was represented by high-risk disease with $42 \%$ of patients having DRI 3 or 4 and active disease in $40 \%$ of patients. The control group (native group) comprised 81 pairmatched patients. The criteria for matching were type of the donor, graft source (bone marrow or PBSC), diagnosis, stage of the disease at the time of the performed HSCT, intensity of the conditioning, age \pm 5 years, CD 34 count $\pm 1 \times 10^{6} / \mathrm{kg}$ and graft versus host disease prophylaxis. The significance of the matching factors was in the order listed above. The resulting groups were well matched and were not significantly different in any of the patient- or transplantation-related factors (Table 1). Median follow up was 25 months, thus the two year outcomes were used in the study.

\section{Transplantation procedures}

Myeloablative conditioning (MAC) was performed with oral busulfan $16 \mathrm{mg} / \mathrm{kg}$ and cyclophosphamide $100-120 \mathrm{mg} / \mathrm{kg}$. Reduced intensity conditioning (RIC) was performed with fludarabine $180 \mathrm{mg} / \mathrm{m}^{2}$ and busulfan $8-10 \mathrm{mg} / \mathrm{kg}$. Patients were assigned to RIC if they were 40 years or older, had hematopoietic cell transplantation-specific comorbidity index (HCT-CI) $\geq 2$, exbited, at least, grade 3 hepatic toxicity during previous therapy, or uncontrolled infection at the start of the conditioning. Patients subjected to second HSCT also received RIC.

GVHD prophylaxis in the post-transplantation cyclophosphamide (PTCy) group consisted of cyclophosphamide (50 $\mathrm{mg} / \mathrm{kg}$ ) administered at days $+3,+4$, tacrolimus $0.03 \mathrm{mg} / \mathrm{kg}$ and mycophenolate mofetil (MMF) $30-45 \mathrm{mg} / \mathrm{kg}$ from day +5. The classical GVHD prophylaxis included either tacrolimus with target concentrations of $5-15 \mathrm{ng} / \mathrm{ml}$, or cyclosporine A with target concentrations of $150-350 \mathrm{ng} / \mathrm{ml}$ from day -1 . As second agents in the prophylaxis regimen we used short-course methotrexate $10-15 \mathrm{mg} / \mathrm{m}^{2}$ at days $+1,+3,+6$ or mycophenolate mofetil (MMF) $30 \mathrm{mg} / \mathrm{kg}$ from day -1 to day +30 .

\section{Clinical definitions}

Time to disease relapse, acute GVHD (aGVHD), moderate to severe chronic GVHD (cGVHD), non-relapse mortality (NRM), overall survival (OS), event-free survival (EFS), and GVHD-relapse free survival (GRFS) were defined as the time from transplantation to the event. All these parameters were calculated for the two-year interval. Incidence of aGVHD was calculated at 125 days after HSCT, and the time frame for the other outcomes was two years. Events for EFS were relapse or death. Events for GRFS were either death, relapse, grades III-IV acute GVHD or systemic therapy-requiring chronic GVHD. The Consensus Conference criteria and NIH criteria were used for aGVHD and cGVHD grading, respectively $[12,13]$. Primary graft failure was defined as the complete absence of donor chimerism in bone marrow biopsy by day +40 . Time to engraftment was calculated as time from HSCT to unsupported neutrophil count $>500 / \mathrm{ul}$ and white blood cell count $>1000 /$ ul for 3 consecutive days. Toxicity was assessed with CTCAE ver. 4.03. Sepsis in the study was defined as systemic inflammatory reaction with 
Table 1. Characteristics of patients and transplantations.

\begin{tabular}{|c|c|c|c|}
\hline Parameter & Cryopreserved graft $(\mathrm{N}=81)$ & Native graft (N=81) & p-value \\
\hline Age & $\begin{array}{l}\text { Adult } 80.72 \% \\
\text { Children } 19.28 \%\end{array}$ & $\begin{array}{l}\text { Adult } 81.01 \% \\
\text { Children } 18.99 \%\end{array}$ & 0.9626 \\
\hline Male, $\%$ & $49.40 \%$ & $50.63 \%$ & 0.8751 \\
\hline Diagnosis & $\begin{array}{l}\text { AML } 37.97 \% \\
\text { ALL } 31.33 \% \\
\text { MDS/MPN 10,84\% } \\
\text { CML } 9.64 \% \\
\text { Lymphoma } 6.49 \% \\
\text { AA } 2.53 \% \\
\text { Solid tumor } 1.20 \%\end{array}$ & $\begin{array}{l}\text { AML } 37.97 \% \\
\text { ALL } 31.33 \% \\
\text { MDS/MPN 9,64\% } \\
\text { CML 10,84\% } \\
\text { Lymphoma 6,49\% } \\
\text { AA } 2.53 \% \\
\text { Solid tumor } 1.20 \%\end{array}$ & 0.9520 \\
\hline Disease risk index & $\begin{array}{l}1-9.64 \% \\
2-48.19 \% \\
3-33.73 \% \\
4-8.43 \%\end{array}$ & $\begin{array}{l}1-17.95 \% \\
2-44.87 \% \\
3-32.05 \% \\
4-6.17 \%\end{array}$ & 0.4227 \\
\hline Donor & $\begin{array}{l}\text { Related } 17.2 \% \\
\text { Unrelated } 82.8 \%\end{array}$ & $\begin{array}{l}\text { Related } 17.2 \% \\
\text { Unrelated } 82.8 \%\end{array}$ & 1.0 \\
\hline Graft source & $\begin{array}{l}\text { BM } 28,4 \% \\
\text { PBSC } 71,6 \%\end{array}$ & $\begin{array}{l}\text { BM 25,9\% } \\
\text { PBSC } 74,1 \%\end{array}$ & 0.7742 \\
\hline Number of HSCT & $\begin{array}{l}\text { First - 88,9\% } \\
\text { Subsequent - } 11.1 \%\end{array}$ & $\begin{array}{l}\text { First }-90.2 \% \\
\text { Subsequent }-9.8 \%\end{array}$ & 0.3622 \\
\hline Conditioning & $\begin{array}{l}\text { RIC } 75.90 \% \\
\text { MAC } 24.10 \%\end{array}$ & $\begin{array}{l}\text { RIC } 78.48 \% \\
\text { MAC } 21.52\end{array}$ & 0.6961 \\
\hline GVHD prophylaxis & $\begin{array}{l}\text { PTCy-based 32.53\% } \\
\text { Tacrolimus } 73.49 \%\end{array}$ & $\begin{array}{l}\text { PTCy-based 34.18\% } \\
\text { Tacrolimus } 67.09 \%\end{array}$ & $\begin{array}{l}0.8241 \\
0.4740\end{array}$ \\
\hline $\begin{array}{l}\text { CD34+ } 10 \times 6 / \mathrm{kg} \text { cells in the } \\
\text { graft, mean } \pm S D\end{array}$ & $4.8 \pm 2.5$ & $5.0 \pm 2.5$ & 0.9266 \\
\hline
\end{tabular}

$\mathrm{AML}=$ acute myeloid leukeina; $\mathrm{ALL}=$ acute lymphoblastic leukemia; $\mathrm{MDS}=$ myelodysplastic syndrome; $\mathrm{MPN}=$ =meloprolipherative neoplasm; $\mathrm{CML}=$ chronic myeloid leukemia; $\mathrm{AA}=$ aplastic anemia; $\mathrm{BM}=$ bone marrow; $\mathrm{PBSC}=$ peripheral blood stem cells; RIC=reduced-intensity conditioning; $\mathrm{MAC}=$ myeloablative conditioning; $\mathrm{PTCy}=$ post-transplantation cyclophosphamide.

microbiologically confirmed bacteremia. The risk of the disease was accessed with disease risk index (DRI) by Armand et al. [14].

\section{Statistical Analysis}

Comparison between the groups was performed by Chisquare test. The comparison of the quantitative parameters between groups were preformed with log-normalized t-test. The survival distributions for OS, EFS, GRFS were calculated using Kaplan-Meier methodology. The comparisons were made using the log-rank test. Cumulative incidence analysis with competing risks for aGVHD, cGVHD, relapse incidence and NRM was performed using Gray test. Relapse and NRM were accounted as competing risks. Early discontinuation of immunosuppression due to relapse or minimal residual disease was considered a competing risk for aGVHD. Donor lymphocyte infusion was considered a competing risk for cGVHD. Multivariate analysis was not performed, because patients were matched by the majority of significant variables. The subgroup analysis was performed for OS. Hetero- geneities between the hazard ratios in the subgroup analysis were tested for significance using the Cochran's $Q$ test, with $\mathrm{df}$ degrees of freedom. Incidence and severity of complications were compared using Mann-Whitney test. Analyses were conducted in SAS 9.3 (SAS Institute, Inc.).

\section{Results}

\section{Engraftment}

There was a trend towards higher incidence of graft failure in the Cryo group ( $15.7 \%$ vs $6.3 \%, \mathrm{p}=0.0588)$. When the graft source was analyzed separately, there was a significant increase in graft failure for BM (26\% vs $0 \%, p=0.025)$, but no difference for peripheral blood ( $12 \%$ vs $9 \%, \mathrm{p}=0.483$ ). Among patients who engrafted there was no difference for the time of neutrophil engraftment (median 19 vs 18 days, $\mathrm{p}=0.345$ in the Cryo and control groups, respectively), white blood cell recovery ( 18 vs 16 days, $\mathrm{p}=0.419)$ and platelet engraftment ( 17 vs 14 days, $\mathrm{p}=0.442$ ). 
A
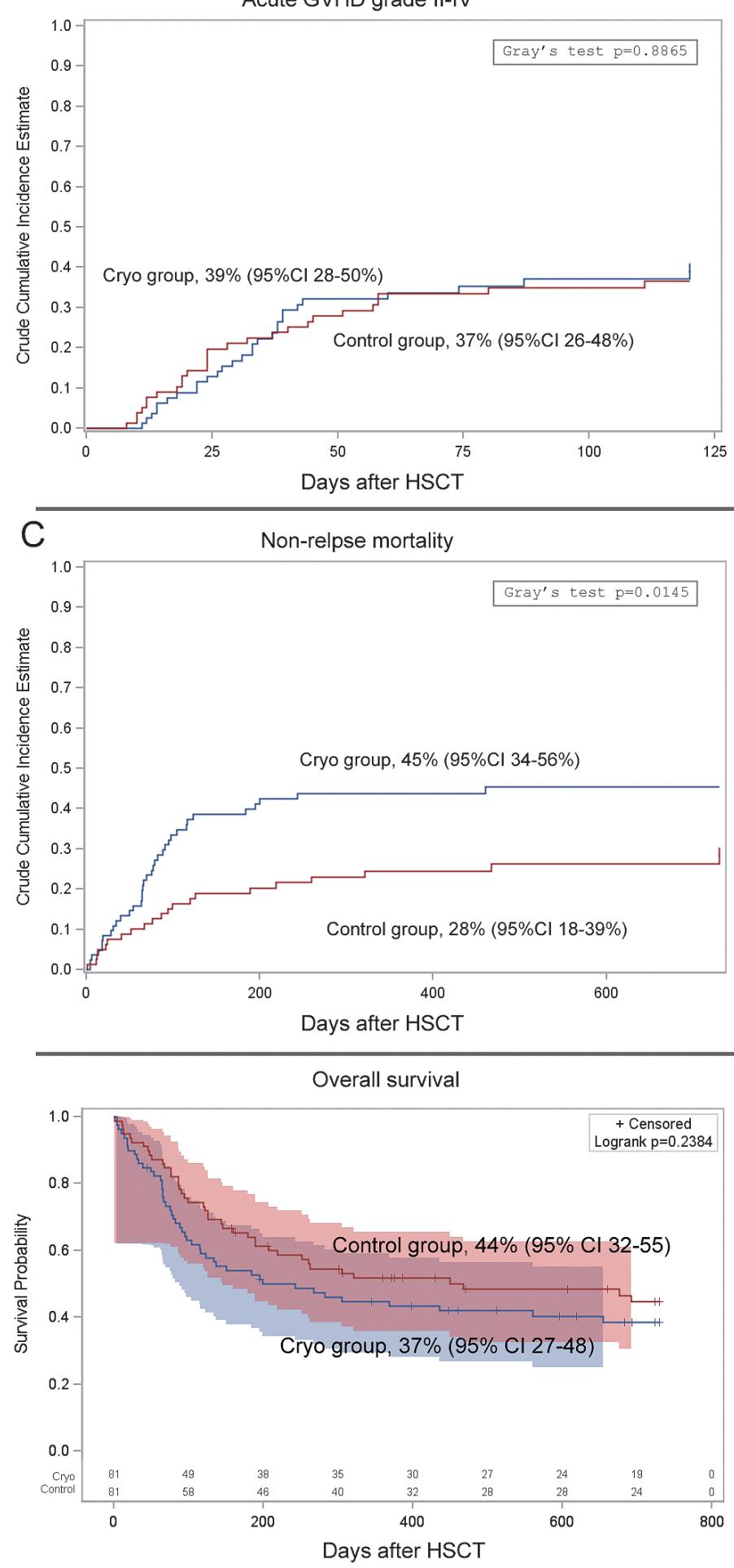

B

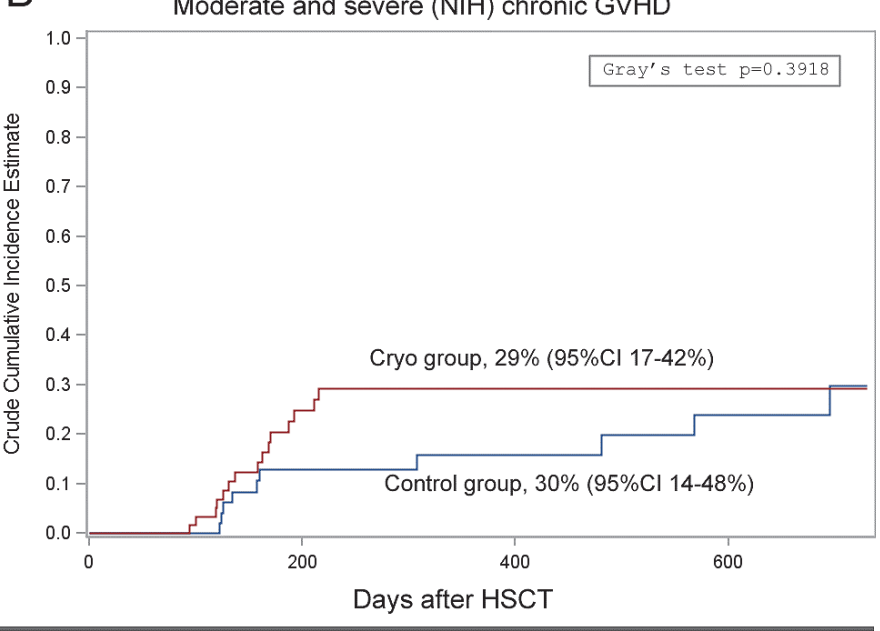

D

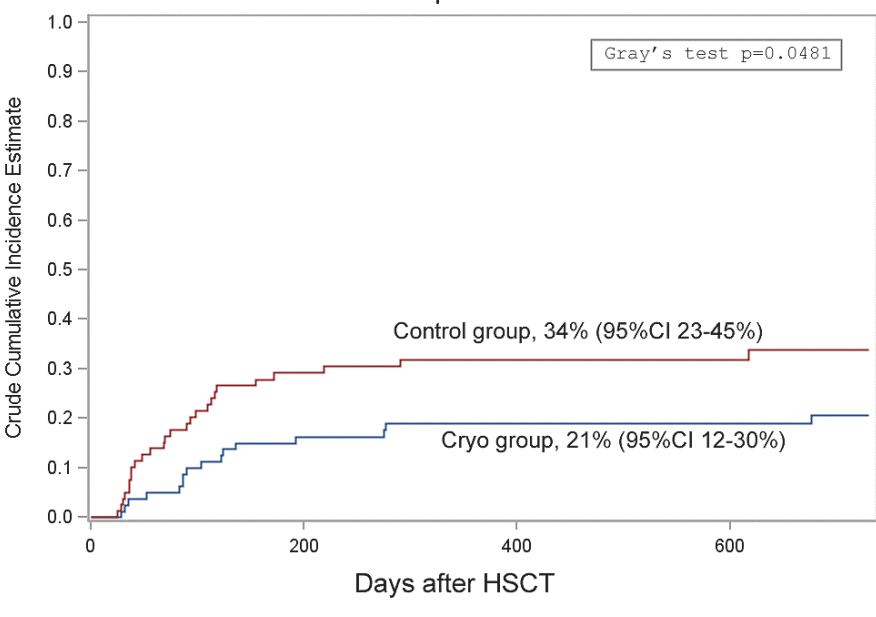

$\mathrm{F}$

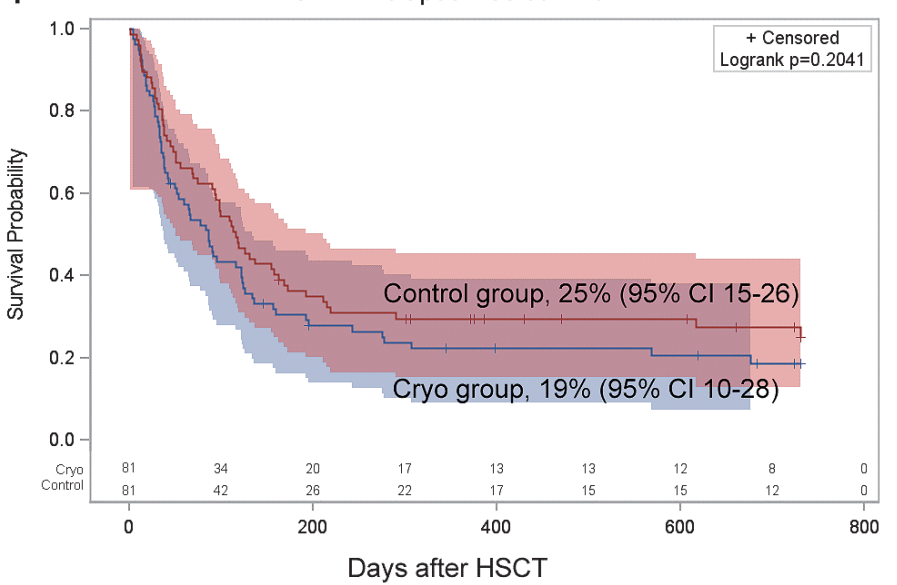

Figure 1. Influence of graft cryopreservation on clinical outcomes of stem cell transplantation A. Acute GVHD grade II-IV; B. Moderate and severe chronic GVHD (NIH); C. Non-relapse mortality; D. Cumulative relapse incidence; E. Overall survival; F. GVHD-relapse-free survival. 


\section{Graft-versus-host disease, mortality and survival}

No differences were observed in the incidence of acute GVHD grade II-IV (39\%, 95\%CI $28-50 \%$ vs $37 \%$, 95\%CI $26-$ $48 \%$ in the Cryo and control groups, respectively, $\mathrm{p}=0.8865$, Fig. 1A) and grade III-IV acute GVHD (25\%, 95\%CI 16-36\% vs $19 \%, 95 \%$ CI $11-29 \%$ in the Cryo and control groups, respectively, $\mathrm{p}=0.4708)$. Incidence of grade I GVHD (14.8\% vs $13,5 \%, \mathrm{p}=0.873$ ) as well as the incidence of steroid-refractory GVHD (9.9\% vs $9.9 \%, \mathrm{p}=1.0)$ were also not different. The incidence of moderate and severe chronic GVHD was also comparable in the study groups: Cryo group, 29\% (95\% CI $17-42 \%$ ) vs Control group, 30\% (95\%CI 14-48\%), $\mathrm{p}=0.3918$, Fig. 1B.

A significantly higher non-relapse mortality was observed for patients with cryopreserved graft: 45\% (95\%CI 34-56\%) vs $28 \%$ (95\% CI $18-39 \%$ ), p=0.0145, Fig. 1C. However, the incidence of relapse was reduced the Cryo group: $21 \%$ (95\% CI $12-30 \%$ ) vs $34 \%$ (95\% CI 23-45\%), $\mathrm{p}=0.0481$, Fig. $1 \mathrm{D}$. This bidirectional differences resulted in absence of statistically significant impact of graft thawing on overall survival (37\%, $95 \%$ CI $27-48 \%$ vs $44 \%$, $95 \%$ CI $32-55 \%$ in the Cryo and control groups, respectively, $\mathrm{p}=0.2384$, Fig. 1E), EFS (35\%, $95 \%$ CI $24-45 \%$ vs $40 \%$, $95 \%$ CI $29-51 \%$, respectively, $\mathrm{p}=0.38)$ and GFRS $(19 \%, 95 \%$ CI $10-28 \%$ vs $25 \%$, $95 \%$ CI 15-26, respectively, $\mathrm{p}=0.2041$, Fig. $1 \mathrm{~F})$.

The subgroup analysis of the OS outcome revealed no differences between cryopreserved and native graft irrespective of the conditioning intensity, graft source, age of the patients, underlying disease, status of the disease and type of donor (p>0.2, Fig. 2).

\section{Complications of transplantation}

In general, toxicity of HSCT was comparable between the groups (Fig. 3), but we observed a significant increase in the incidence of acute clinically significant renal toxicity (30\% vs $10 \%, \mathrm{p}=0.0046)$. The mean maximal creatinine observed after HSCT was $143 \pm 108$ vs $114 \pm 65 \mu \mathrm{mol} / \mathrm{l}$ in the Cryo and control groups, respectively. Borderline differences were observed in the incidence of sepsis before engraftment (24\% vs $13 \%, \mathrm{p}=0.0681)$ and severe sepsis before engraftment $(17 \%$ vs $8 \%, \mathrm{p}=0.0981$ ). Although relatively high incidence of VOD (15\%) for predominantly RIC regimen was observed in the Cryo group, the difference was not statistically significant.

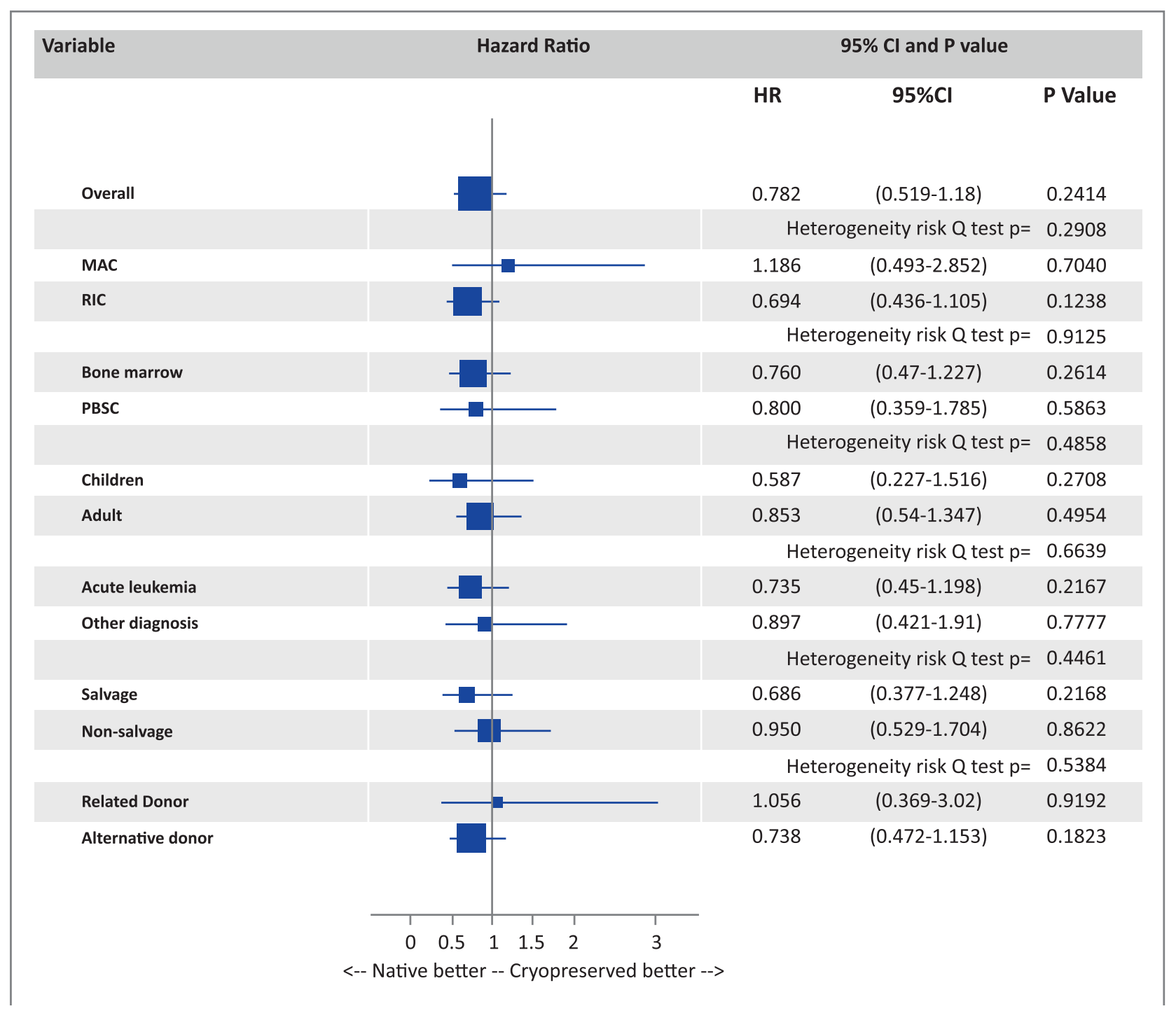

Figure 2. Subgroup analysis of overall survival 
50

60

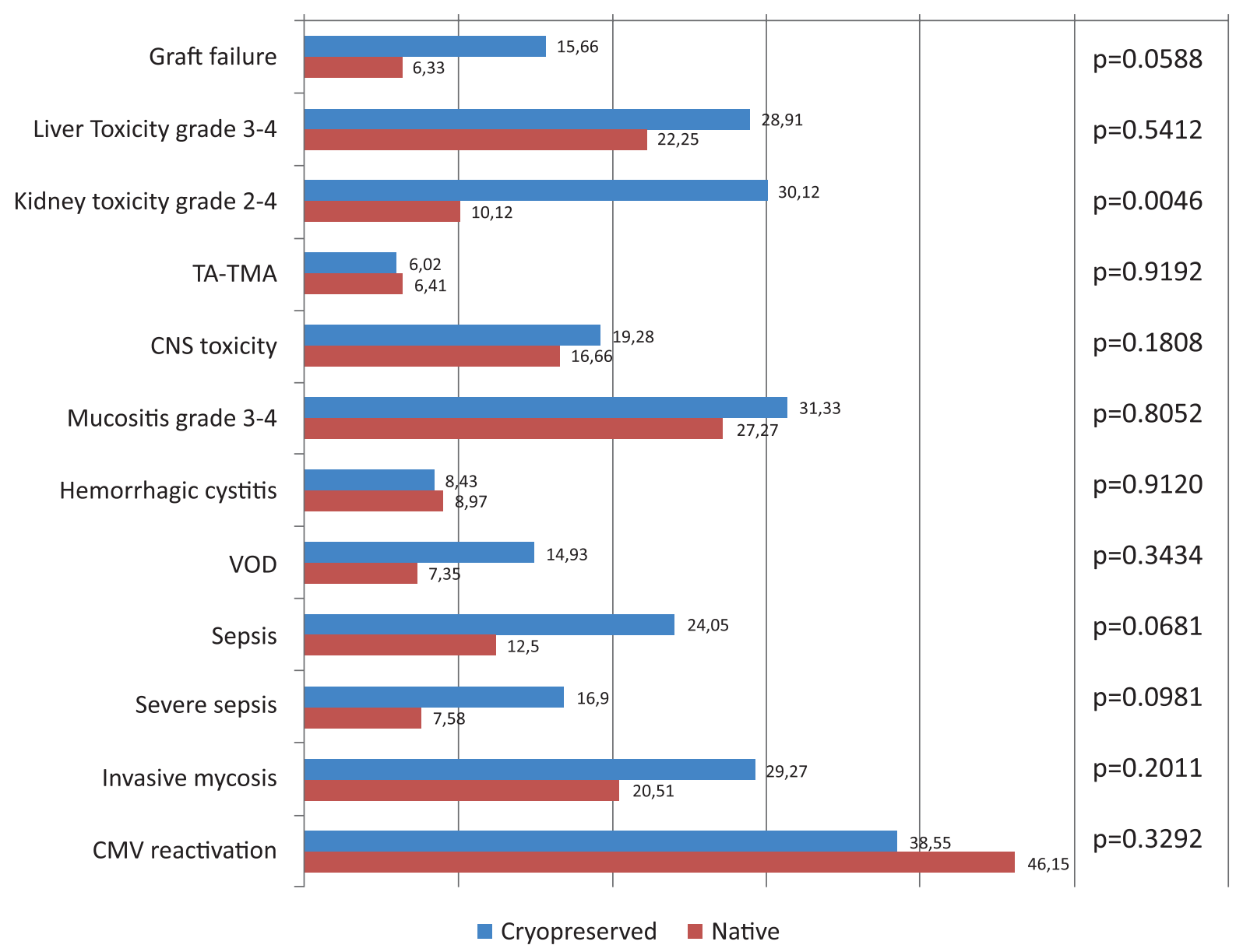

Figure 3. Complications of stem cell transplantation

\section{Discussion}

In this well-matched cohort of patients, we have shown that the survival of patients after HSCT with cryopreserved graft is not significantly compromised. Also we have not observed any differences in the incidence of acute and chronic GVHD. These results are comparable to the ones previously reported by Medd et al. [11], despite their cohort included predominantly matched related donors and PBSC only. Despite the comparable OS levels, we observed that NRM was significantly higher in the Cryo group, which was compensated by lower relapse risk. To our knowledge, this observation hadnot been previously reported in the literature.

The increment in non-relapse mortality was primary driven by higher incidence of graft failures. This corresponds to the data previously reported by M. Lioznov et al. [9]. In our study we observed increased incidence in the BM, but not in PBSC group. However, the number of graft failures in our dataset is relatively low to draw a definitive conclusion. Since primary graft failure is a multifactorial event [6] with significant impact of anti-HLA antibodies [15], other antibody types [16], microenvironment abnormalities, particularly in MDS and MPN [17], and other potential factors, this difference in graft failure should be confirmed in large registry studies. Nonetheless, the current understanding of immune mechanisms behind graft failure might partially explain the increased incidence of this complication after freezing the graft. The release of specific antigens during thawing, particularly from granulocytes, might trigger both the antibody-mediated and T-cell-mediated rejection [18].

The other complication leading to non-relapse mortality was the tendency to higher incidence of sepsis. It is unlikely that the mechanisms behind this observation are related to the cryopreservation of the graft. It was rather due to difference between groups. For the majority of patients in the Cryo group, the reason for freezing the graft was an unexpected infection. This indicates that this group might have been more prone to infections. In allo HSCT recipients this is usually associated by iron overload [19], and the groups were not matched by this parameter. Also the Cryo group included patients in whom the remissions were reinduced before HSCT, using high-dose cytarabine with fludarabine. This mode of chemotherapy is usually associated with relatively high incidence of bloodstream infections [20], and recurrence of septic episodes after HSCT has previously been reported [21].

The finding about reduced risk of relapse in the study group also lacks logical explanation, since the incidence of acute and chronic GVHD was not different between the groups, and it is hard to speculate about the augmentation of graft-versus-leukemia affect. Despite the groups were matched by the 
disease type and stage, the abovementioned mechanism of re-induction close to the start of the conditioning might play a role. Although chemotherapy and conditioning were not sequential like in certain protocols for high-risk leukemia [22], the factor of timing is likely to play a role in the observed results.

\section{Conclusion}

Despite certain differences between the groups compared and non-randomized study design, we have demonstrated that cryopreservation of allogeneic graft is a viable option in case of complications that increase the risk of HSCT, however the benefit from postponing a transplant should be weighed against the possible risk of primary graft failure. The results of the study require confirmation in the muticenter setting or in the studies with international registry data.

\section{Acknowledgements}

The authors declare no conflict of interest.

\section{References}

1. Passweg JR, Baldomero H, Bader P, Basak GW, Bonini C, Duarte R, Dufour C, Kröger N, Kuball J, Lankester A, Montoto S, Nagler A, Snowden JA, Styczynski J, Mohty M, and EMBT. Is the use of unrelated donor transplantation leveling off in Europe? The 2016 European Society for Blood and Marrow Transplant activity survey report. Bone Marrow Transplant. 2018 Mar 14. doi: 10.1038/s41409-018-0153-1.

2. Craddock C, Hoelzer D, Komanduri KV. Current status and future clinical directions in the prevention and treatment of relapse following hematopoietic transplantation for acute myeloid and lymphoblastic leukemia. Bone Marrow Transplant. 2018 May 31. doi: 10.1038/s41409-018-0203-8.

3. He GL, Chang YJ, Xu LP, Zhang XH, Wang Y, Liu KY, Huang XJ. Impact of pre-transplant pulmonary infection developed in horizontal laminar flow unit on the outcome of subsequent allogeneic hematopoietic stem cell transplantation. J Thorac Dis. 2016;8(8):2219-2225.

4. Yamamoto W, Fujii E, Matsumoto K, Yamamoto E, Aoki J, Tanaka M, Ishigatsubo Y, Kanamori H. Prognostic value of pretransplant serum C-reactive protein in patients receiving reduced-intensity conditioning allogeneic hematopoietic stem cell transplantation. Int J Hematol. 2016;103(4):444452 .

5. Ringdén O, Barrett AJ, Zhang MJ, Loberiza FR, Bolwell BJ, Cairo MS, Gale RP, Hale GA, Litzow MR, Martino R, Russell JA, Tiberghien P, Urbano-Ispizua A, Horowitz MM. Decreased treatment failure in recipients of HLA-identical bone marrow or peripheral blood stem cell transplants with high CD34 cell doses. Br J Haematol. 2003;121(6):874-885.

6. Mattsson J, Ringden O, Storb R. Graft failure after allogeneic hematopoietic cell transplantation. Biol Blood Marrow Transplant. 2008;14(1 Suppl 1):165-170.
7. Lasky LC, Van Buren N, Weisdorf DJ, Filipovich A, McGlave P, Kersey JH, McCullough J, Ramsay NK, Blazar BR. Successful allogeneic cryopreserved marrow transplantation. Transfusion. 1989;29(2):182-184.

8. Stockschläder M, Hassan HT, Krog C Krüger W, Löliger C, Horstman M, Altnöder M, Clausen J, Grimm J, Kabisch $\mathrm{H}$, Zander A. Long-term follow-up of leukaemia patients after related cryopreserved allogeneic bone marrow transplantation. Br J Haematol. 1997;96(2):382-386.

9. Lioznov M, Dellbrügger C, Sputtek A, Fehse B, Kröger $\mathrm{N}$, Zander AR. Transportation and cryopreservation may impair haematopoietic stem cell function and engraftment of allogeneic PBSCs, but not BM. Bone Marrow Transplant. 2008 Jul;42(2):121-128.

10. Frey NV, Lazarus HM, Goldstein SC. Has allogeneic stem cell cryopreservation been given the 'cold shoulder'? An analysis of the pros and cons of using frozen versus fresh stem cell products in allogeneic stem cell transplantation. Bone Marrow Transplant. 2006; 38(6):399-405.

11. Medd P, Nagra S, Hollyman D, Craddock C, Malladi R. Cryopreservation of allogeneic PBSC from related and unrelated donors is associated with delayed platelet engraftment but has no impact on survival. Bone Marrow Transplant. 2013;48(2):243-248.

12. Przepiorka D, Weisdorf D, Martin P, Klingemann HG, Beatty P, Hows J, Thomas ED. 1994 Consensus Conference on Acute GVHD Grading. Bone Marrow Transplant. $1995 ; 15: 825-828$.

13. Filipovich AH, Weisdorf D, Pavletic S, Socie G, Wingard JR, Lee SJ, Martin P, Chien J, Przepiorka D, Couriel D, Cowen EW, Dinndorf P, Farrell A, Hartzman R, Henslee-Downey J, Jacobsohn D, McDonald G, Mittleman B, Rizzo JD, Robinson M, Schubert M, Schultz K, Shulman H, Turner M, Vogelsang $\mathrm{G}$, Flowers ME. National Institutes of Health consensus development project on criteria for clinical trials in chronic graft-versus-host disease: I. Diagnosis and staging working group report. Biol Blood Marrow Transplant. 2005;11:945956.

14. Armand P, Kim HT, Logan BR, Wang Z, Alyea EP, Kalaycio ME, Maziarz RT, Antin JH, Soiffer RJ, Weisdorf DJ, Rizzo JD, Horowitz MM, Saber W. Validation and refinement of the Disease Risk Index for allogeneic stem cell transplantation. Blood. 2014;123(23):3664-3671.

15. Ciurea SO, Cao K, Fernadez-Vina M, Kongtim P, Malki MA, Fuchs E, Luznik L, Huang XJ, Ciceri F, Locatelli F, Aversa F, Castagna L, Bacigalupo A, Martelli M, Blaise D, Handgretinger R, Roy DC, O'Donnell P, Bashey A, Lazarus HM, Ballen K, Savani BN, Mohty M, Nagler A. The European Society for Blood and Marrow Transplantation (EBMT) Consensus Guidelines for the Detection and Treatment of Donor-specific Anti-HLA Antibodies (DSA) in Haploidentical Hematopoietic Cell Transplantation. Bone Marrow Transplant. 2018;53(5):521-534.

16. Barge AJ, Johnson G, Witherspoon R, Torok-Storb B. Antibody-mediated marrow failure after allogeneic bone marrow transplantation. Blood. 1989;74(5):1477-1480. 
17. Santamaria C, Muntión S, Rosón B, Blanco B, López-Villar O, Carrancio S, Sánchez-Guijo FM, Díez-Campelo M, Alvarez-Fernández S, Sarasquete ME, de las Rivas J, González M, San Miguel JF, Del Cañizo MC. Impaired expression of DICER, DROSHA, SBDS and some microRNAs in mesenchymal stromal cells from myelodysplastic syndrome patients. Haematologica. 2012;97(8):1218-1224.

18. Chrysler G, McKenna D, Schierman T, Kadidlo D, Askari S, Miller J, Clay M, McCullough J. Cellular characteristics of cord blood and cord blood transplantation. In: Broxmeyer $\mathrm{H}$, editor. Cord Blood: Biology, Immunology, Banking and Clinical Transplantation. AABB; Bethesda, MD: 2004. pp. 219-258.

19. Shaheen M, Ivanova MO, Moiseev IS, Bondarchuk SV, Afanasyev BV. Impact of initial serum ferritin on early postHSCT complications: a single-center study.Cell Ther Transplant. 2016; 5(2): 40-49.

20. Estey E, Thall P, Andreeff M, Beran M, Kantarjian H, O'Brien S, Escudier S, Robertson LE, Koller C, Kornblau S, et al. Use of granulocyte colony-stimulating factor before, during, and after fludarabine plus cytarabine induction therapy of newly diagnosed acute myelogenous leukemia or myelodysplastic syndromes: comparison with fludarabine plus cytarabine without granulocyte colony-stimulating factor. J Clin Oncol. 1994;12(4):671-678.

21. Hakki M, Limaye AP, Kim HW, Kirby KA, Corey L, Boeckh M. Invasive Pseudomonas aeruginosa infections: high rate of recurrence and mortality after hematopoietic cell transplantation. Bone Marrow Transplant. 2007;39(11):687693.

22. Saure C, Schroeder T, Zohren F, Groten A, Bruns I, Czibere A, Galonska L, Kondakci M, Weigelt C, Fenk R, Germing U, Haas R, Kobbe G. Upfront allogeneic blood stem cell transplantation for patients with high-risk myelodysplastic syndrome or secondary acute myeloid leukemia using a FLAMSA-based high-dose sequential conditioning regimen. Biol Blood Marrow Transplant. 2012;18(3):466-472. 


\title{
Попарный сравнительный анализ криоконсервиро- ванных и нативных трансплантатов для взрослых реципиентов и детей при аллогенной гемопоэтиче- ской трансплантации стволовых клеток
}

\author{
Елена В. Бабенко, Иван С. Моисеев, Михаил М. Канунников, Александр Л. Алянский, Дмитрий Э. Певцов, \\ Анастасия В. Фролова, Анна А. Осипова, Татьяна А. Быкова, Олеся В. Паина, Елена И. Дарская, \\ Людмила С. Зубаровская, Сергей Н. Бондаренко, Инна В. Маркова, Борис В. Афанасьев \\ НИИ детской онкологии, гематологии и трансплантологии им. Р. М. Горбачевой Первого Санкт-Петербургского \\ государственного медицинского университета, Санкт-Петербург, Российская Федерация
}

\section{Резюме}

Криоконсервация (Крио) трансплантата является неотъемлемой частью процедуры аутологичной трансплантации гемопоэтических стволовых клеток (ТГСК), тем не менее, в литературе крайне мало данных о безопасности и эффективности аллогенной ТГСК после стадии замораживания. Для определения клинического значения криоконсервации трансплантата было проведено исследование методом парных сравнений между 81 пациентом, получившим инфузию замороженного аллогенного трансплантата, и 81 пациентом, получившим инфузию нативного трансплантата. Критериями парного подбора были вариант и стадия заболевания, тип донора, источник трансплантата, возраст пациента, интенсивность кондиционирования, профилактика реакции «трансплантат против хозяина» (РТПХ) и количество CD34-положительных клеток в трансплантате. В исследуемой группе 83\% выполнена неродственная ТГСК, 72\% получили инфузию стволовых клеток периферической крови и $40 \%$ относились к группе «спасения». При сравнении группы Крио и контрольной группы не было выявлено различий в частоте острой РTПX II-IV степени (39\% vs $37 \%, \mathrm{p}=0,89)$, средней и тяжелой хронической РТПХ (29\% vs 30\%, p=0,39), общей выживаемости (37\% vs $44 \%, \mathrm{p}=0,24)$, бессобытийной выживаемости (35\% vs $40 \%, \mathrm{p}=0,38)$ и выживаемости без рецидива и РТПХ ( $19 \%$ vs $25 \%$, p=0,20), соответственно. Тем не менее, трансплантационная летальность (ТЛ) была значимо выше в группе Крио ( $45 \%$ vs $28 \%$, p=0,015), что частично компенсировалось снижением вероятности рецидива ( $21 \%$ vs $34 \%, \mathrm{p}=0,048)$. Основной причиной повышения ТЛ был тренд к большей частоте первичного неприживления трансплантата (15,7\% vs $6.3 \%, \mathrm{p}=0,059)$ и сепсиса в период аплазии кроветворения ( $24 \%$ vs $13 \%, \mathrm{p}=0,068)$. Различий в скорости приживления нейтрофилов и тромбоцитов выявлено не было. Частота осложнений трансплантации была сравнима в двух группах, за исключением повышения вероятности развития нефротоксичности II-IV степени в группе криоконсервации (30\% vs $10 \%, \mathrm{p}=0,0046)$. В заключение можно сказать, что исследование показало сравнимые результаты при использовании замороженного и нативного трансплантата. Выявленное повышение частоты первичного неприживления трансплантата, сепсиса и трансплантационной летальности требуют подтверждения в многоцентровых исследованиях.

\section{Ключевые слова}

Трансплантация гемопоэтических стволовых клеток, аллогенная, криоконсервирование трансплантата, замораживание трансплантата, первичное неприживление трансплантата. 